\title{
EGU21-2128
}

https://doi.org/10.5194/egusphere-egu21-2128

EGU General Assembly 2021

(c) Author(s) 2021. This work is distributed under

the Creative Commons Attribution 4.0 License.

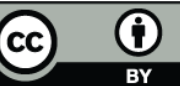

\section{Hydrogeological characterization and groundwater quality assessment in an atoll island (Magoodhoo Island of Faafu Atoll - Maldives)}

Chiara Zanotti, Barbara Leoni, Veronica Nava, Luca Fallati, Marco Rotiroti, and Tullia Bonomi University of Milano - Bicocca, DISAT - Department of Earth and Environmental Sciences, Milano, Italy (chiara.zanotti@unimib.it)

Although freshwater is a vital resource for domestic and productive purposes, it is a very limited and vulnerable resource on atoll islands. Besides precipitations, on coral atolls groundwater is the only source of fresh water, usually extending below sea level in the form of a thin fresh water lens. Several possible environmental hazard can affect the availability of the resource, ranging from salinization induced by overexploitation to deterioration induced by unsustainable land use. Therefore, it becomes important to understand and characterize atolls' islands aquifers and identify sustainable and hazardous practices to support a wise and farsighted resource management.

In this work a detailed characterization of the aquifer of Magoodhoo Island (Faafu Atoll - Maldives) is performed, through a hydrogeological mapping and groundwater quality characterization.

The Magoodhoo Island, with an area of $0.213 \mathrm{~km}^{2}$, is a typical and representative native inhabited island (c.a. 850 people) not affected by intense tourist traffic.

In order to collect topographic data, a drone survey was performed, with a fly altitude set at $80 \mathrm{~m}$ a.s.l. to reach a $4 \mathrm{~cm}$ ground pixel resolution obtaining a Digital Elevation Model (DEM), with a resolution of $10 \mathrm{~cm}$.

Groundwater depth ( $m$ a.s.l.) was measured in 37 monitoring wells using a water level dipper to obtain a piezometric map of the aquifer. Furthermore, two CTD-diver were used to measure groundwater depth in a monitoring well and tidal oscillation of the sea level simultaneously with a time-resolution of 15 minutes for 5 days.

Groundwater quality data were collected in 36 monitoring point, including a rainwater tank and analysed for physico-chemical parameters including water temperature $(\mathrm{T})$, electrical conductivity (EC), $\mathrm{pH}$, dissolved oxygen (DO), and $\mathrm{DO}$ saturation (DO\%), major ions $\left(\mathrm{Cl}, \mathrm{NO}_{3}-\mathrm{N}, \mathrm{NO}_{2}-\mathrm{N}_{1} \mathrm{NH}_{4}-\mathrm{N}\right.$, total phosphorus (TP), $\mathrm{Si}, \mathrm{SO}_{4}, \mathrm{Ca}, \mathrm{Mg}, \mathrm{Na}, \mathrm{Sr}$, and $\mathrm{K}$ ) and metals/semi-metals ( $\mathrm{As}, \mathrm{Pb}, \mathrm{Ni}, \mathrm{Fe}, \mathrm{Mn}$ and Zn).

Results show that groundwater depth varies spatially from around $1 \mathrm{~m}$ a.s.l. in the north-eastern 
part (ocean side) to $-1.2 \mathrm{~m}$ a.s.l. in the central-western part. On the time scale, a good correlation between groundwater level and tidal fluctuations is observed and a tidal lag of about 3.5 hours was determined through a cross-correlation analysis.

Groundwater quality data highlighted different pollution point sources. The main impact on water quality was related to domestic activities producing a great amount of organic matter and wastewater. Other cases of local pollution were identified and associated to farm (poultry) and gardening activities (fertilization).

This study allowed for an in-depth knowledge of the Maghoodoo island aquifer system, which can be extended to other Maldivian and atoll islands constituting a valuable support for future water resource planning and management. 